\title{
Antioxidant content and activity of the seaweed Saccharina latissima: a seasonal perspective
}

Marinho, Goncalo Silva; Sørensen, Ann-Dorit Moltke; Safafar, Hamed; Pedersen, Anja H.; Løvstad Holdt, Susan

Published in:

Journal of Applied Phycology

Link to article, DOI:

10.1007/s10811-018-1650-8

Publication date:

2019

Document Version

Peer reviewed version

Link back to DTU Orbit

Citation (APA):

Marinho, G. S., Sørensen, A-D. M., Safafar, H., Pedersen, A. H., \& Løvstad Holdt, S. (2019). Antioxidant content and activity of the seaweed Saccharina latissima: a seasonal perspective. Journal of Applied Phycology, 31(2), 1343-1354. https://doi.org/10.1007/s10811-018-1650-8

\section{General rights}

Copyright and moral rights for the publications made accessible in the public portal are retained by the authors and/or other copyright owners and it is a condition of accessing publications that users recognise and abide by the legal requirements associated with these rights.

- Users may download and print one copy of any publication from the public portal for the purpose of private study or research.

- You may not further distribute the material or use it for any profit-making activity or commercial gain

- You may freely distribute the URL identifying the publication in the public portal 


\section{Antioxidant content and activity of the seaweed Saccharina latissima: a seasonal perspective}

Gonçalo Silva Marinho,

Email: gosm@food.dtu.dk

AQ1

Ann-Dorit Moltke Sørensen,

Hamed Safafar, 1

Anja H. Pedersen, 1

Susan L. Holdt, 1

1 National Food Institute, Technical University of Denmark, DK-2800 Kongens Lyngby, Denmark

Received: 15 April 2018 / Accepted: 27 September 2018

\section{Abstract}

Seaweeds have been receiving increasing attention as a promising natural source of antioxidants. The present study aimed at evaluating seasonal variations in the antioxidant content and activity of the sugar kelp, Saccharina latissima, cultivated at two sites in Denmark from May 2013 to May 2014. The extraction performance of two solvents, methanol and ethyl acetate, was compared, with methanol extracts resulting generally in higher total phenolic content (TPC), total flavonoid content (TFC), and total antioxidant capacity (TAC), all determined spectrophotometrically. Phenolic compounds (phloroglucinol, phenolic acids, and flavonoids) were evaluated by HPLCDAD. TPC was higher in November and January (1.23-2.41 $\mathrm{mg} \mathrm{GAE} \mathrm{g}^{-1}$ DM) compared to that in September. Contrary, the highest TFC was found in September $\left(4.56-4.83 \mathrm{mg} \mathrm{RE} \mathrm{g}^{-1} \mathrm{DM} ; p<0.05\right)$. The pigment profile did not change seasonally, whereas fucoxanthin and chlorophyll $a$ were the most abundant. Fucoxanthin concentration was lower in September compared to all other months $\left(261-665 \mu \mathrm{g} \mathrm{g}{ }^{-1} \mathrm{DM} ; p<0.05\right)$. TAC was significantly higher in

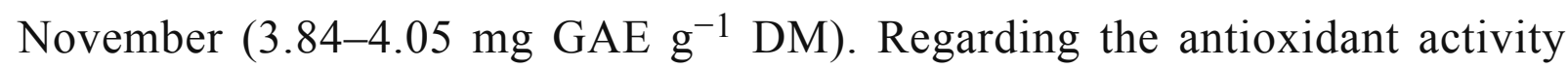


$(\mathrm{DPPH})$, there was no significant difference in the $\mathrm{IC}_{50}$ between seasons, although it was tendentiously lower in September and November $(0.42-$ $0.49 \mathrm{mg} \mathrm{mL} \mathrm{mL}^{-1}$ ). Statistical analysis revealed a strong positive correlation between TPC and TAC; additionally, TPC and TFC contributed positively for the radical scavenging activity. There was no significant difference for all the analyzed variables between cultivation sites. This study reveals marked seasonal variations, and high biological variability (difference among replicates) in the antioxidant content of S. latissima, and substantially lower antioxidant capacity compared to other species such as Fucus sp., which needs to be taken into account when considering seaweed as a commercial source of antioxidants.

\section{Keywords}

Sugar kelp
Phaeophyta
TPC
Polyphenols
Flavonoids
HPLC
DPPH

\section{Introduction}

Seaweeds have been used as a valuable food source in Asian countries since ancient times, while in Europe they constitute a largely unexploited resource, used mainly as raw material for the phycocolloid industry (Arasaki and Arasaki 1983; Bixler and Porse 2011; Mouritsen 2013). With a global seaweed aquaculture production of 30 million tonnes in 2015 (FAO 2018), seaweeds are regarded as a valuable source of vitamins, minerals, polyunsaturated fatty acids, protein, and dietary fibers (Holdt and Kraan 2011; Tabarsa et al. 2012). Lately, seaweeds have been receiving increasing attention in the Western world as a source of bioactive compounds including specific polysaccharides, proteins, lipids, and polyphenols which have reported anti-viral, anti-tumor, antiinflammatory, and anti-lipidemic activities among many others (Holdt and Kraan 2011; Pal et al. 2014). Particularly, antioxidants have been linked to disease risk reduction and health promotion, due to their ability to attenuate oxidative stress in the body (Shahidi et al. 2012). Antioxidants can also be used to prevent lipid oxidation in lipid-rich or lipid-enriched (fortified) products such as foods and cosmetics, and thus increase their shelf-life. Moreover, seaweed extracts have shown to reduce oxidation in fish oil-enriched emulsion systems (Farvin and 
Jacobsen 2015; Hermund et al. 2015; Karadağ et al. 2017; Poyato et al. 2017). While synthetic antioxidants have been widely used in food preservation, their use is currently restricted due to safety concerns (Wattenberg 1986; Sherwin 1990). In this context, there is a great need for natural antioxidant sources with potential to be used as ingredients in the development of new functional foods, cosmetics, and pharmaceuticals. The bioactive substances with antioxidant activity found in seaweeds include phenolic compounds, $\alpha$-tocopherol (vitamin E), ascorbic acid (vitamin C), carotenoids such as fucoxanthin and $\beta$-carotene, and phycobiliproteins (Rodríguez-Bernaldo de Quirós et al. 2010).

Phlorotannins are a subgroup of polyphenolic compounds formed entirely by polymerization of phloroglucinol (Koivikko et al. 2005; Singh and Sidana 2013). Phlorotannins have been isolated for several brown seaweed species belonging to Fucaceae, Alariaceae, Sargassaceae, Cystoseiraceae, Laminariaceae, and Ishigeaeceae, and while their concentration is generally above $2 \%$, in some cases it can account for up to $25-30 \%$ of dry algal biomass (Singh and Sidana 2013). Reported biological activities of phlorotannins include antioxidant, antiinflammatory, anti-diabetic, anti-HIV, anti-cancer, and enzyme inhibitory activities (Singh and Sidana 2013; Jacobsen et al. 2018).

Flavonoids are another subgroup of phenolic compounds functioning as UV screen in higher plants, among many other important functions (Rozema et al. 2002), which until recently had only been found in terrestrial plants.

Nevertheless, flavonoids have recently been structurally identified in microalgae and seaweeds. Klejdus et al. (2010) detected the presence of isoflavones, a class of isoflavonoids, in brown (Undaria pinnatifida, Sargassum muticum, and Sargassum vulgare) and red seaweed species (Hypnea spinella, Halopytis incurvus, Chondrus crispus, and Porphyra sp.) using UHPLC-MS/MS. The same methodology was later used by Goiris et al. (2014) to identify different classes of flavonoids in microalgae. Additionally, Rodríguez-Bernaldo de Quirós et al. (2010) identified catechins (flavanols, a class of flavonoids) in red (Palmaria palmata and Porphyra spp.) and brown seaweeds (Laminaria ochroleuca and Himanthalia elongata) confirmed by HPLC-MS.

Saccharina latissima is a North Atlantic kelp species which has been successfully cultivated both in land-based and open-water aquaculture, as monoculture and in integrated multi-trophic aquaculture (IMTA; e.g., Peteiro and Freire 2013; Handå et al. 2013; Marinho et al. 2015c; Azevedo et al. 2016). It contains significant levels of total polyphenols and presents fucoxanthin as major carotenoid (Haugan and Liaaen-Jensen 1994; Rodríguez-Bernaldo de Quirós et al. 2010). Other brown seaweed species such as the fucoid Fucus vesiculosus have shown higher content of phenolic compounds and thereby 
antioxidant capacity than S. latissima. However, the well-established cultivation techniques and relatively high content of antioxidant compounds make $S$. latissima potentially a sustainable natural source of antioxidants (Jacobsen et al. 2018).

Seaweeds present marked seasonal variations in their composition of, e.g., proteins and lipids, (e.g., Marinho et al. 2015a, b) which may also be the case for antioxidants and this needs to be taken into consideration when evaluating their potential as a source of antioxidant compounds and their antioxidant capacity. A seasonal pattern in the concentration of pigments, with generally lower concentrations in summer and higher concentrations in winter, has been reported for a number of seaweed species and linked to changes in light availability and nutrient concentrations in the seawater (Stengel and Dring 1998; Schmid et al. 2017). Increased fucoxanthin content is usually associated with increased lightharvesting efficiency, an adaptation to low-light conditions such as depth or selfshading (Ramus et al. 1977; Fortes and Lüning 1980). Fucoxanthin plays a lightharvesting role but it also likely has a photoprotective function in the seaweed (Fariman et al. 2016). The lipid-soluble carotenoid fucoxanthin, mainly found in the brown seaweed, could be of commercial interest, not only for the antioxidant capacity but also due to other bioactive effects such as anti-obesity, anti-cancer, and UV-B protective effect (Holdt and Kraan 2011).

AQ2

Similarly, seasonal changes in the content of polyphenols have been reported to be impacted by irradiance levels, but also temperature, nutrient availability, precipitation, and salinity (Kamiya et al. 2010; Mannino et al. 2014; Fariman et al. 2016). Moreover, biotic factors such as grazing pressure, reproductive state, and stage within the life cycle have been correlated with changes in the polyphenols content (Steinberg 1995; Stiger et al. 2004). More specifically and also in relation to our study, Yates and Peckol (1993) found that the polyphenolic concentrations of Fucus vesiculosus were higher (and up to twice as high) in populations from a low-nitrogen site compared to those from a high-nitrogen site (where also the tissue-N content was higher). Cultivating seaweed near a nutrient source (e.g., IMTA) could in that respect possibly change the phenolic content of the seaweed, and thereby also the antioxidant capacity of the biomass.

The present study aimed to (1) evaluate seasonal changes in the content of total phenolics, total flavonoids, and pigments, and the subsequent antioxidant capacity, based on standard assays, of $S$. latissima cultivated in IMTA and at a reference site; (2) tentatively detect selected phenolic acids and flavonoids by HPLC-DAD; and (3) compare the extraction performance of two different solvents, methanol and ethyl acetate, based on the recovery of the target 
antioxidant compounds. Finally, the future perspectives of using S. latissima as potential source of antioxidant are discussed and compared to other sources such as microalgae and higher plants.

\section{Materials and methods}

\section{Chemicals}

Sulfuric acid, Folin-Ciocalteu reagent, and aluminum chloride were from Merck (Germany); ammonium molybdate, potassium acetate, DPPH (2,2-diphenyl-1picrylhydrazyl), and sodium phosphate were from Sigma (Germany).

Gallic acid, rutin, and BHT (butylated hydroxytoluene) used as antioxidant standards were from Sigma-Aldrich (Germany). Likewise, additional standards used for the analysis of phenolic compounds including phenolic acids (caffeic, protocatechuic, gentisic, hydroxybenzoic, chlorogenic, syringic, salicylic, coumaric, and ferulic acids), flavonoids (catechol, quercitrin, morin, hesperidin, myricetin, catechin, quercetin, and naringenin), and phloroglucinol were from Sigma-Aldrich. Standards for pigment analysis were from DHI (Hørsholm, Denmark). All solvents applied were of HPLC grade and from VWR International (Søborg, Denmark). Phosphoric acid and tetrabutylammonium acetate were from Merck and Sigma-Aldrich, respectively. HPLC grade water was prepared using a Milli-Q Advantage A10 water deionizing system from Millipore Corporation (USA).

\section{Experimental design, sampling, and sample preparation}

Samples were harvested at two commercial cultivation areas by Hjarnø Havbrug $\mathrm{A} / \mathrm{S}$ in vicinity of Horsens Fjord, in the inner Danish waters. The integrated multi-trophic aquaculture (IMTA) facility was located in the area As Vig (55 $47.529^{\prime} \mathrm{N}, 10^{\circ} 03.027^{\prime} \mathrm{E}$ ); seaweeds cultivated here were approximately $100 \mathrm{~m}$ away from a blue mussel SmartFarm ${ }^{\mathrm{TM}}$ (35 tubes including nets) and $500 \mathrm{~m}$ from rainbow trout (Oncorhynchus mykiss) open net-pen farm $\left(175 \mathrm{t} \mathrm{year}^{-1}\right)$. The reference site (REF) seaweed cultivation area $\left(100 \mathrm{ha} ; 55^{\circ} 49.045^{\prime} \mathrm{N}, 10^{\circ}\right.$ $06.824^{\prime}$ E) was located at approximately $2 \mathrm{~km}$ away from the IMTA, and therefore not impacted by nutrient derived from the production of fish and mussels (remineralization). Seaweed commercial production consisted of $7 \mathrm{~km}$ and $90 \mathrm{~km}$ of cultivation lines (seeded with seedlings of S. latissima) deployed at the IMTA and REF site, respectively, during 2011-2013. On 21 May 2013, prior to the experimental period, some ropes were moved from the REF site to the IMTA site for comparison. For this reason, in May 2013, biomass samples were taken solely at the REF site. For more details, see Marinho et al. (2015c). 
The cultivated biomass was sampled bimonthly in triplicates (each replicate consisting of at least 10 individual seaweeds randomly selected from each dropper; vertical cultivation line), except in May $2013(n=2)$. Samples were freeze-dried, ground to fine powder using a Siebtechnik Screening disc mill TS 250 , and hereafter stored at $-80^{\circ} \mathrm{C}$ until further analyses. Bimonthly analyses were performed for most of the chemical composition (Marinho et al. 2015a, b, c), and samples covering different seasons were chosen for the antioxidant analyses performed in the present study (May 2013, September 2013, November 2013, January 2014, and May 2014).

Dry matter (DM) was determined after drying the biomass in an oven at $105{ }^{\circ} \mathrm{C}$ until constant weight. Prior to the analysis, bioactive compounds, i.e., phenolics, flavonoids, and pigments, were extracted with solvent from the freeze-dried seaweed samples. Methanol and ethyl acetate were tested for the extraction of bioactive compounds from the REF samples for total phenolic content (TPC), total flavonoid content (TFC), and total antioxidant capacity (TAC) assays. Based on the extraction performance, methanol was selected and used in the subsequent extractions.

\section{Extractions of antioxidants}

The extraction was performed according to Safafar et al. (2015), however, with some modifications. Briefly, dried powder of seaweed $(0.2 \mathrm{~g})$ was weighed into centrifuge tubes, $5 \mathrm{~mL}$ solvent (either methanol or ethyl acetate) was added, and the tubes were placed in a sonicator for $30 \mathrm{~min}$. Thereafter, the samples were centrifuged (3500 rpm, ca. $2164 \mathrm{~g}$ for $10 \mathrm{~min}$ ) and supernatant was collected in a new tube. The pellets were resuspended and extractions repeated twice. The solvent was evaporated under nitrogen flow. When the extracts were completely dried, they were stored in the freezer $\left(-18{ }^{\circ} \mathrm{C}\right)$. Prior to the analyses, the dried powders were dissolved in $1 \mathrm{~mL}$ solvent (either methanol or ethyl acetate). One extraction was performed for each of the three sampling replicates for all sampling points (except REF in May 2013, $n=2$ ).

\section{Total antioxidant capacity}

This method was performed according to Prieto et al. (1999). Extracts (100 $\mu \mathrm{L})$ were mixed with $1 \mathrm{~mL}$ TAC reagent solution $(0.6 \mathrm{M}$ sulfuric acid, $28 \mathrm{mM}$ sodium phosphate, and $4 \mathrm{mM}$ ammonium molybdate). The samples were then left in a water bath $\left(95^{\circ} \mathrm{C}, 90 \mathrm{~min}\right)$. Thereafter, the samples were cooled to room temperature and then the absorbance was measured at $695 \mathrm{~nm}$. Sample blank (only solvent without sample) was included. Gallic acid was used as standard and the measured absorbance was converted to gallic acid equivalents from a 
calibration curve with gallic acid. For the calibration curve, gallic acid was dissolved in the same solvent as the extracts (either methanol or ethyl acetate) in the concentration range from 10 to $100 \mu \mathrm{g} \mathrm{m}^{-1}$.

\section{Total phenolic content}

Extracts $(100 \mu \mathrm{L})$ were mixed with Folin-Ciocalteu's reagent $(0.75 \mathrm{~mL}$, ratio 1:10). The mixture was left for $5 \mathrm{~min}$ at room temperature. Thereafter, $6 \%$ sodium carbonate $(0.75 \mathrm{~mL})$ was added. The samples were placed in the dark for $90 \mathrm{~min}$ at room temperature, and the absorbance was measured at $725 \mathrm{~nm}$ (Singleton and Rossi 1965; Farvin and Jacobsen 2013). Sample blank (only solvent without sample) was included. Gallic acid was used as standard, and the measured absorbance was converted to gallic acid equivalents from a calibration curve with gallic acid. For the calibration curve, gallic acid was dissolved in the same solvent as the extracts (either methanol or ethyl acetate) in the concentration range from 10 to $100 \mu \mathrm{g} \mathrm{mL}^{-1}$.

\section{Total flavonoid content}

This method was performed according to Safafar et al. (2015). Extracts (100 $\mu \mathrm{L})$ were mixed with $10 \%$ aluminum chloride $(100 \mu \mathrm{L}), 1 \mathrm{M}$ potassium acetate $(100 \mu \mathrm{L})$, and distilled water $(900 \mu \mathrm{L})$. The samples were left for $30 \mathrm{~min}$ (room temperature, darkness) and the absorbance was measured at $415 \mathrm{~nm}$. For extracts with ethyl acetate, acetone $(200 \mu \mathrm{L})$ was added prior to the absorbance measurements, due to the abrupt two phases that were present. Sample blank (only solvent without sample) was included. Rutin was used as standard and the measured absorbance was converted to rutin equivalents from a calibration curve with rutin. For the calibration curve, rutin was dissolved in the same solvent as the extracts (either methanol or ethyl acetate) in the concentration range from 30 to $180 \mu \mathrm{g} \mathrm{mL}^{-1}$.

\section{Radical scavenging activity (DPPH)}

Different dilutions of the extracts $(100 \mu \mathrm{L})$ were transferred to wells in a microplate and $0.1 \mathrm{mM} \mathrm{DPPH}$ in methanol $(100 \mu \mathrm{L})$ was added (Farvin et al. 2014). The absorbance $(517 \mathrm{~nm})$ was measured after $30 \mathrm{~min}$ (room temperature, darkness) in a microplate reader (Synergy 2 BioTek, USA). Results are expressed as $\mathrm{IC}_{50}$, i.e., the concentration of extract needed to obtain $50 \%$ inhibition. BHT was included in the assay as a positive control since a concentration of $0.91 \mathrm{mM}$ of BHT is giving approximately $70 \%$ inhibition.

\section{Phenolic acids and flavonoids evaluated by HPLC}


The extracts were filtered using $0.45-\mu \mathrm{m}$ filters (Millipore) before analysis. Chlorophylls and carotenoids were largely removed from the extracts by adsorbing these pigments on an Oasis MCX ion exchange column $(60-\mu \mathrm{m}$ particle size, $6 \mathrm{~mL}, 150 \mathrm{mg}$ sorbent, Waters, USA), in order to reduce noise (unwanted peaks) in the chromatograms. The analyses were performed by reverse-phase HPLC using an Agilent 1100 Liquid Chromatograph (Agilent Technologies, USA) equipped with a DAD (Agilent G13158). The separation was carried out on a Prodigy ODS-3 column $250 \mathrm{~mm} \times 46 \mathrm{~mm}$ with $5-\mu \mathrm{m}$ particle size from Phenomenex (USA). The analysis was performed in the gradient mode using phosphoric acid in deionized water $(\mathrm{pH}=3)$ as mobile phase A and methanol-acetonitrile $(50: 50, v / v)$ as mobile phase B. The gradient elution program was as follows: $0 \mathrm{~min}(95 \% \mathrm{~A}+5 \% \mathrm{~B}), 2 \min (60 \% \mathrm{~A}+40 \%$ B), $20 \min (100 \%$ B), $35 \min (95 \% \mathrm{~A}+5 \% \mathrm{~B})$. Total acquisition time was 40 min. Separation was performed at $25{ }^{\circ} \mathrm{C}$. The flow rate was set at $0.9 \mathrm{~mL} \mathrm{~min}^{-1}$ and the injection volume was $20 \mu \mathrm{L}$. Detection was performed at $235,255,280$, and $320 \mathrm{~nm}$. Spectral recording for identification purposes was facilitated by using a photodiode detector with a spectral range from 200 to $400 \mathrm{~nm}$.

\section{Pigments}

Extraction and analysis of the pigments was done by a method described by Safafar et al. (2015). Samples were extracted by pure methanol containing BHT (butylated hydroxytoluene) in a sonication bath (Branson Ultrasonics, USA) in the dark, at a temperature lower than $5{ }^{\circ} \mathrm{C}$ and for $15 \mathrm{~min}$. The separation was carried out by HPLC on a Zorbax Eclipse C 8 column $150 \mathrm{~mm} \times 46 \mathrm{~mm}$ with 3.5$\mu \mathrm{m}$ particle size from Phenomenex. The mobile phase was a mixture of solvent A ( $70 \%$ methanol $+30 \%$ of $0.028 \mathrm{M}$ tetrabutylammonium acetate in water) and solvent $\mathrm{B}$ (methanol) at a flow rate of $1.1 \mathrm{~mL} \mathrm{~min}^{-1}$. The gradient program was started with $5 \%$ of B and then increased to $95 \%$ in 27 min, kept constant for $7 \mathrm{~min}$ and then changed to $100 \%$ in $1 \mathrm{~min}$ and kept constant for $5 \mathrm{~min}$. Total acquisition time was $40 \mathrm{~min}$. Identification of peaks and calibration was done by individual standard for each pigment. Detection of pigments and internal standard (BHT) was done at $440 \mathrm{~nm}$ and $280 \mathrm{~nm}$, respectively.

\section{Data treatment}

All results are presented as mean \pm standard deviation, corresponding to three experimental replicates $(n=3)$, except in May $2013(n=2)$. Analyses were run in duplicate to evaluate analytical precision. 
A permutational ANOVA (using Euclidean distances) was used to test the effect of time (random) and site (REF and IMTA; fixed), and time and solvent (methanol and ethyl acetate; fixed) on various response parameters: TPC, TFC, and TAC assays, and concentration of fucoxanthin. Whenever a significant difference between sample means or interaction of factors was revealed by PERMANOVA $(p<0.05)$, a posteriori analysis (pairwise test) was performed. Pairwise comparisons were performed among levels of factors, including within individual levels of other factors in the case of a significant interaction. A oneway PERMANOVA was used to test the effect of harvest time on DPPH radical scavenging activity (PERMANOVA package in PRIMER+; Anderson et al. 2008; type III sum of squares and unrestricted permutation (9999) on raw data; $\alpha=0.05)$.

Multiple regression and multivariate data analysis as partial least squares coefficient method were carried out using STATGRAPHICS software, version Centurion XVI (StatPoint Technologies Inc., USA).

\section{Results}

Effect of methanol and ethyl acetate extraction on TPC, TFC, and TAC (REF site)

TPC was significantly higher in S. latissima samples extracted by methanol compared with those extracted using ethyl acetate $(F=18.64, p<0.05$; Fig. 1$)$. TPC ranged from 0.84 to $2.41 \mathrm{mg} \mathrm{GAE}^{-1}$ algal DM for methanol extraction and 0.056 to $1.253 \mathrm{mg} \mathrm{GAE} \mathrm{g}^{-1} \mathrm{DM}$ for ethyl acetate extraction. Seasonal variation on TCP was also significant $(F=3.47, p<0.05)$.

\section{Fig. 1}

Total phenolic content (TPC; $\mathrm{mg} \mathrm{GAE}^{-1} \mathrm{DM}$ ) of Saccharina latissima harvested in different seasons on the REF site, extracted by methanol or ethyl acetate solvents. Data are mean $\pm \mathrm{SD} ; n=3$ except in May $2013(n=2)$ 


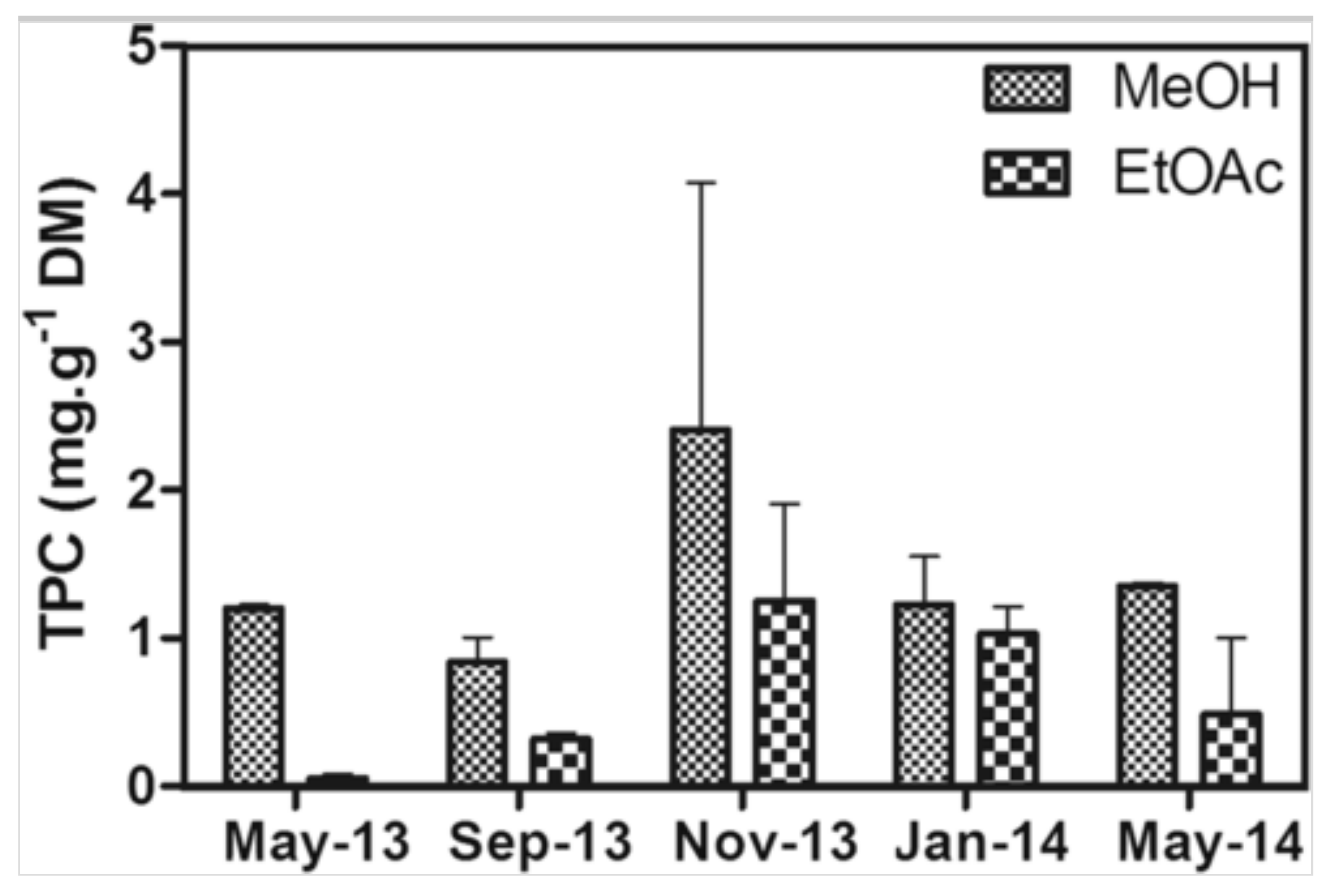

The statistical analysis on TFC revealed a significant interaction between factors (i.e., solvent and harvest time, $p<0.05$ ). Methanol extraction yielded higher TFC in May and September 2013 (2.00-4.56 $\left.\mathrm{mg} \mathrm{RE} \mathrm{g}^{-1} \mathrm{DM}\right)$ compared to ethyl

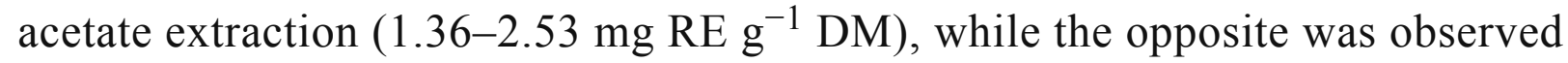
from November 2013 to May $2014 ; 1.59-2.43 \mathrm{mg} \mathrm{RE} \mathrm{g}^{-1} \mathrm{DM}$ compared to 2.90-4.26 mg RE g ${ }^{-1}$ DM (Fig. 2).

Fig. 2

Total flavonoid content (TFC; mg RE $\mathrm{g}^{-1} \mathrm{DM}$ ) of Saccharina latissima harvested in different seasons on the REF site, extracted by methanol or ethyl acetate solvents. Data are mean $\pm \mathrm{SD} ; n=3$ except in May $2013(n=2)$

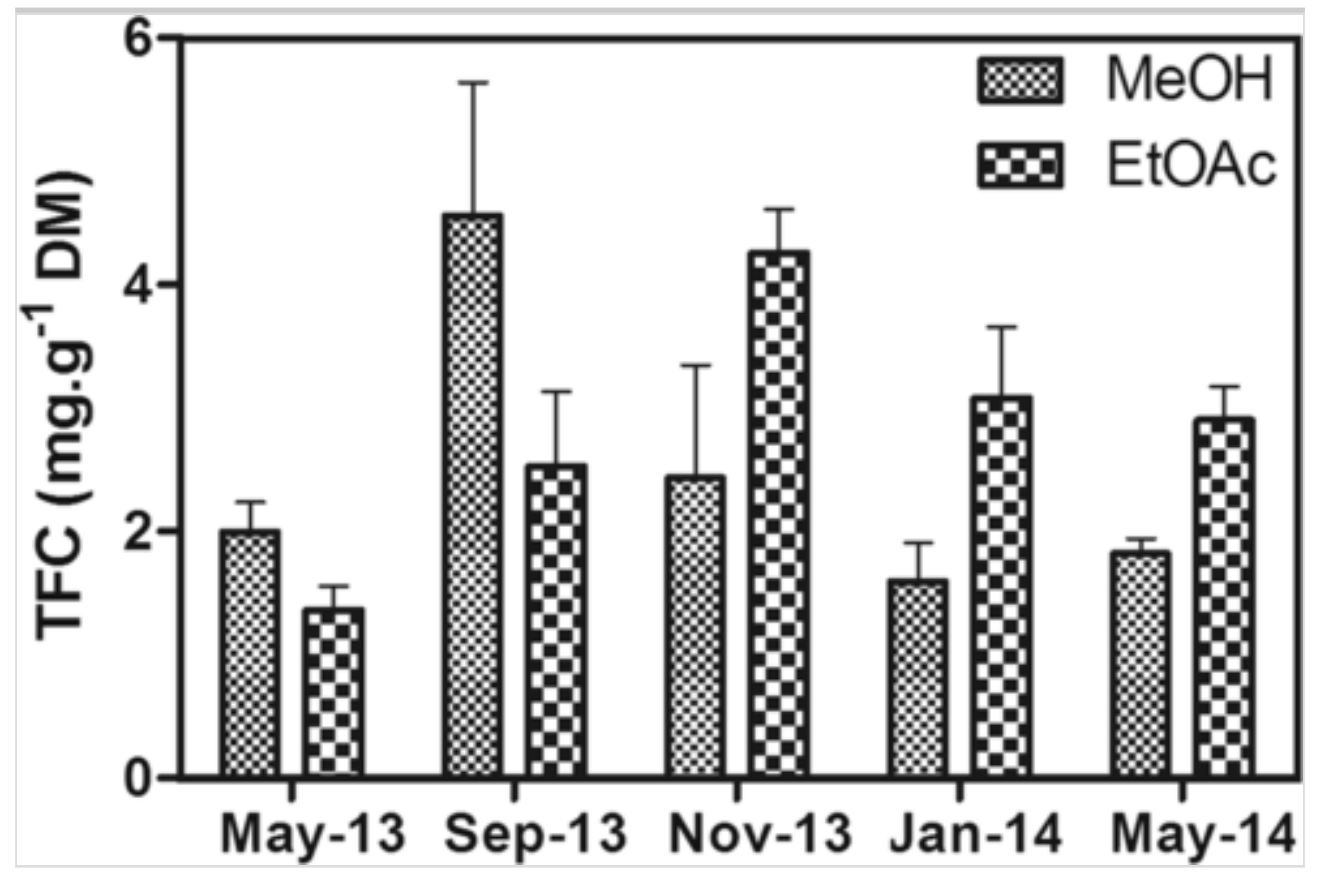


TAC was significantly higher in S. latissima samples extracted by methanol, regardless of the harvest time $(F=65.09, p<0.05$; Fig. 3$)$. TAC ranged from 2.36 to $3.84 \mathrm{mg} \mathrm{GAE} \mathrm{g}^{-1} \mathrm{DM}$ for methanol extraction and 0.263 to $1.07 \mathrm{mg} \mathrm{GAE} \mathrm{g}^{-1} \mathrm{DM}$ for ethyl acetate extraction.

Fig. 3

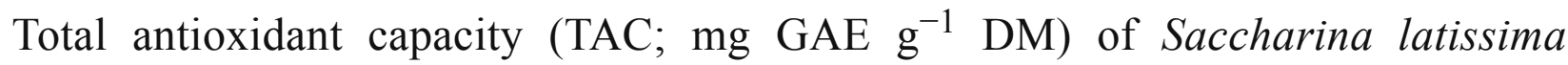
harvested in different seasons on the REF site, extracted by methanol or ethyl acetate solvents. Data are mean $\pm \mathrm{SD} ; n=3$ except in May $2013(n=2)$

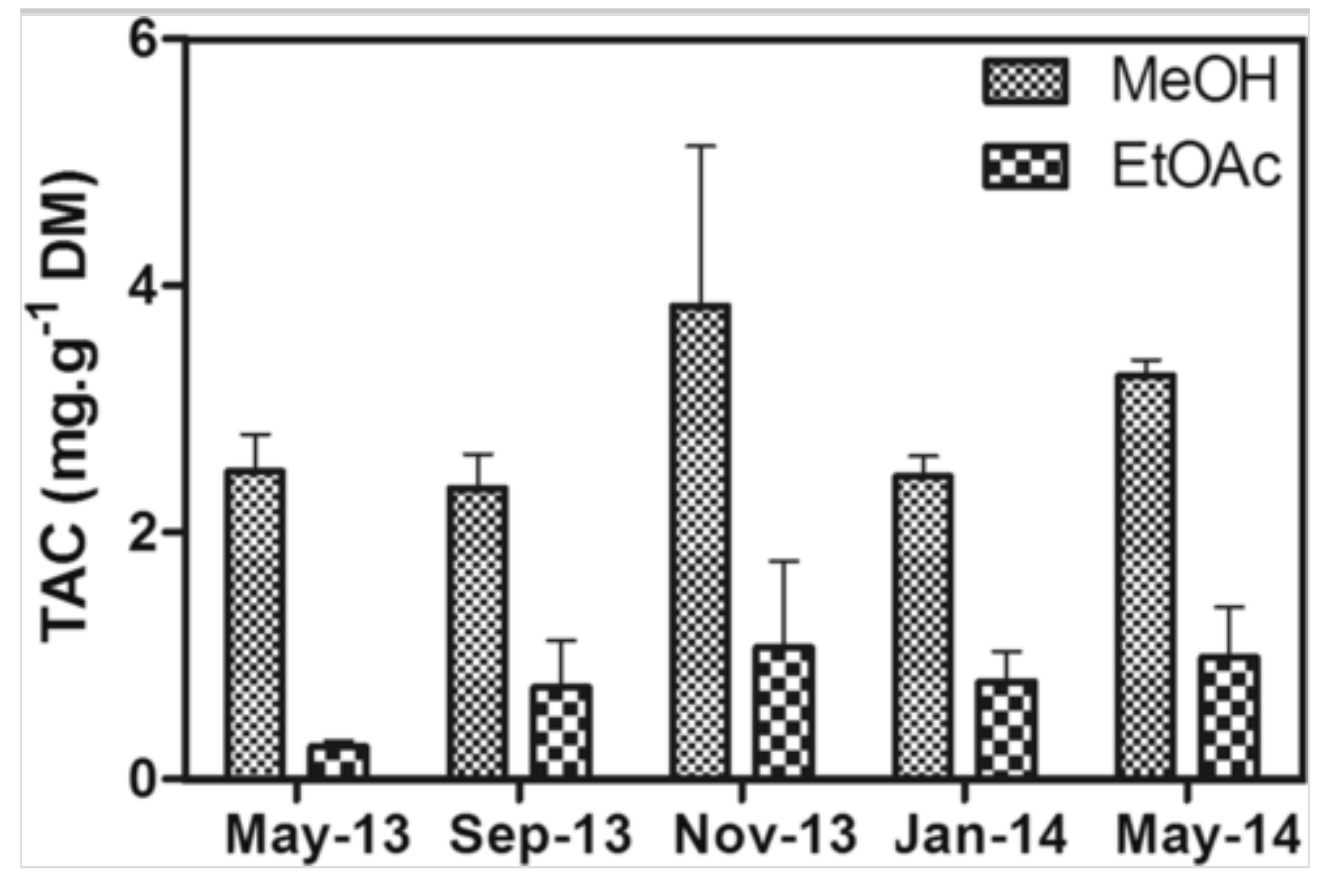

Based on the results from the TPC, TFC, and TAC assays obtained using the two different solvents, methanol was selected to be used in the subsequent extractions.

Effect of season and cultivation site on the pigment concentration, antioxidant content, and activity (REF and IMTA sites)

Generally, cultivation site did not result in significant difference on the tested parameters (TPC, $F=0.002, p=0.97$; TFC, $F=1.44, p=0.31$; and TAC, $F=$ $0.04, p=0.86$ ), while significant seasonal differences were identified for the TPC, TFC, and TAC assays.

TPC was higher in November and January (1.23-2.41 $\left.\mathrm{mg} \mathrm{GAE} \mathrm{g}^{-1} \mathrm{DM}\right)$ compared to September (0.84-1.10 $\left.\mathrm{mg} \mathrm{GAE}^{-1} \mathrm{DM} ; p<0.05\right)$, but it was not significantly different from May 2014 (1.08-1.35 mg GAE g ${ }^{-1}$ DM; Fig. 4). 
Fig. 4

Total phenolic contenteompounds (TPCs) in Saccharina latissima harvested in different seasons, and cultivated both at the IMTA and REF sites. Different letters represent significant difference $(p<0.05)$ between months. Data are mean $\pm \mathrm{SD}$; $n=3$

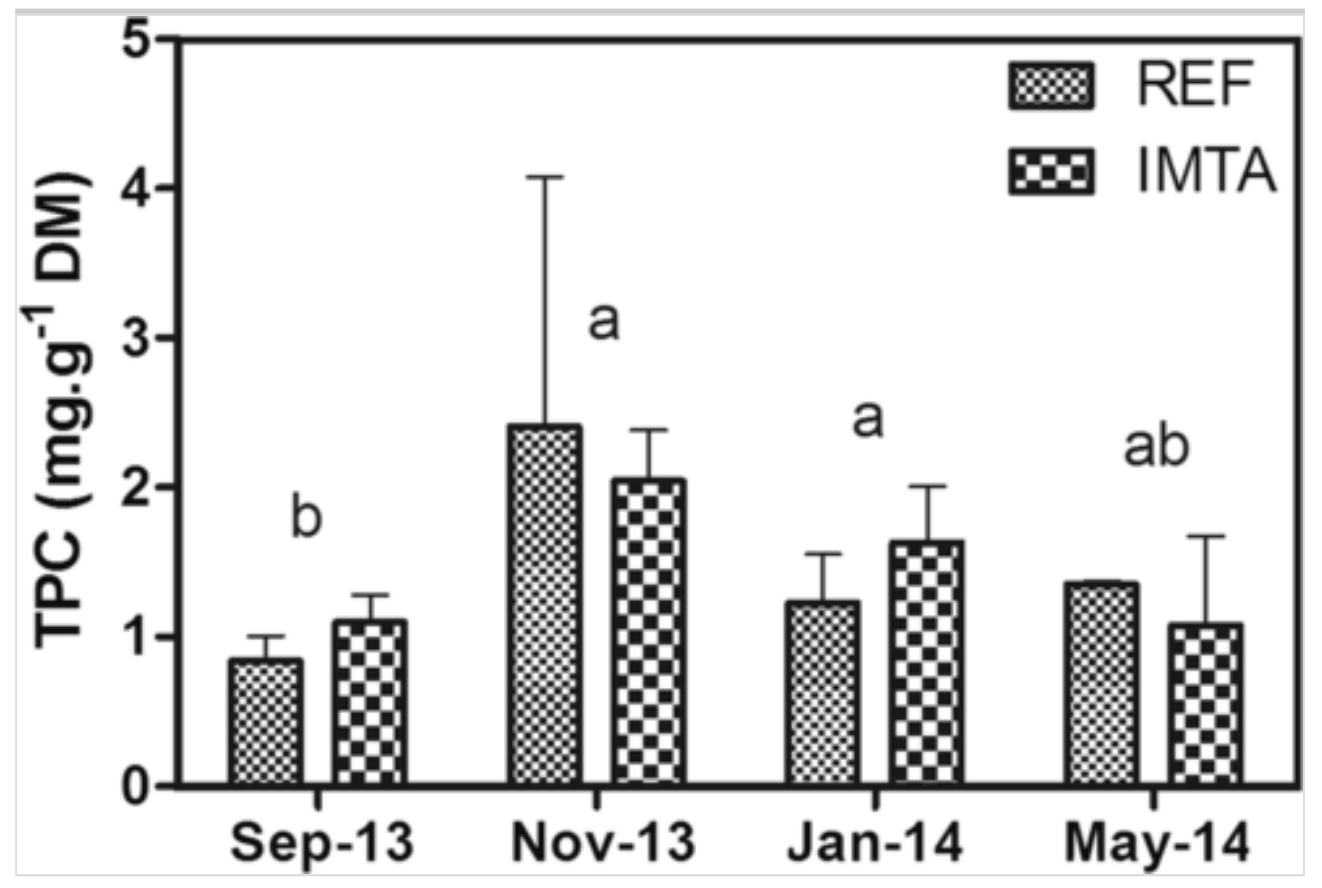

The highest TFC was found in September $\left(4.56-4.83 \mathrm{mg} \mathrm{RE} \mathrm{g}^{-1} \mathrm{DM} ; p<0.05\right)$, whereas there was no significant difference between all other harvest times (1.40-2.59 mg RE g ${ }^{-1}$ DM; Fig. 5).

Fig. 5

Total flavonoid content (TFC) of Saccharina latissima harvested in different seasons, and cultivated both at the IMTA and REF sites. Different letters represent significant difference $(p<0.05)$ between months. Data are mean $\pm \mathrm{SD} ; n=3$ 


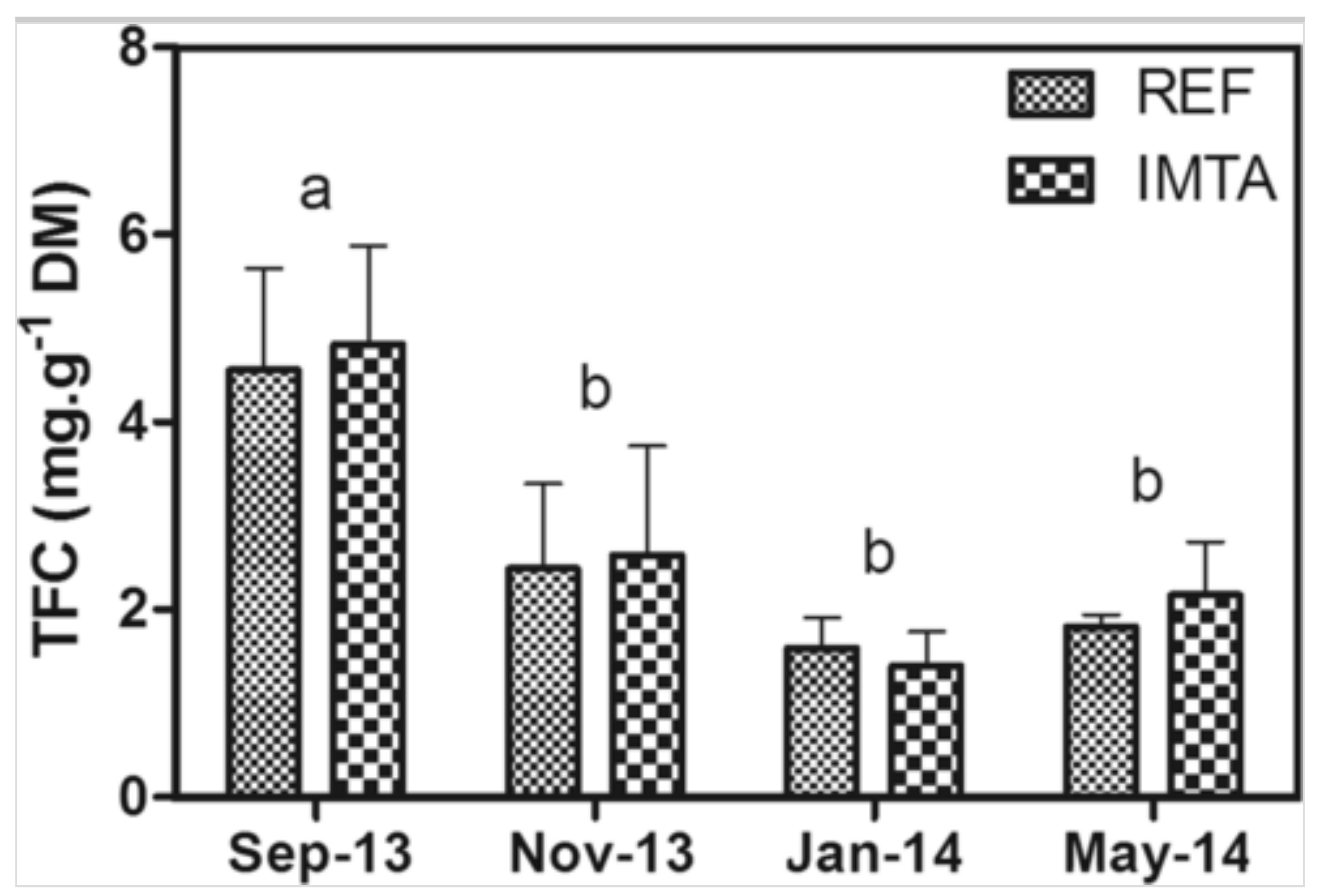

TAC was significantly higher in November (3.84-4.05 $\left.\mathrm{mg} \mathrm{GAE} \mathrm{g}^{-1} \mathrm{DM}\right)$, compared to September and January (2.14-2.88 $\left.\mathrm{mg} \mathrm{GAE} \mathrm{g}^{-1} \mathrm{DM}\right)$, but similar to May 2014 (2.63-3.27 mg GAE g ${ }^{-1} \mathrm{DM} ; p>0.05$; Fig. 6).

Fig. 6

Total antioxidant capacity (TAC) of Saccharina latissima harvested in different seasons, and cultivated both at the IMTA and REF sites. Different letters represent significant difference $(p<0.05)$ between months. Data are mean $\pm \mathrm{SD} ; n=3$

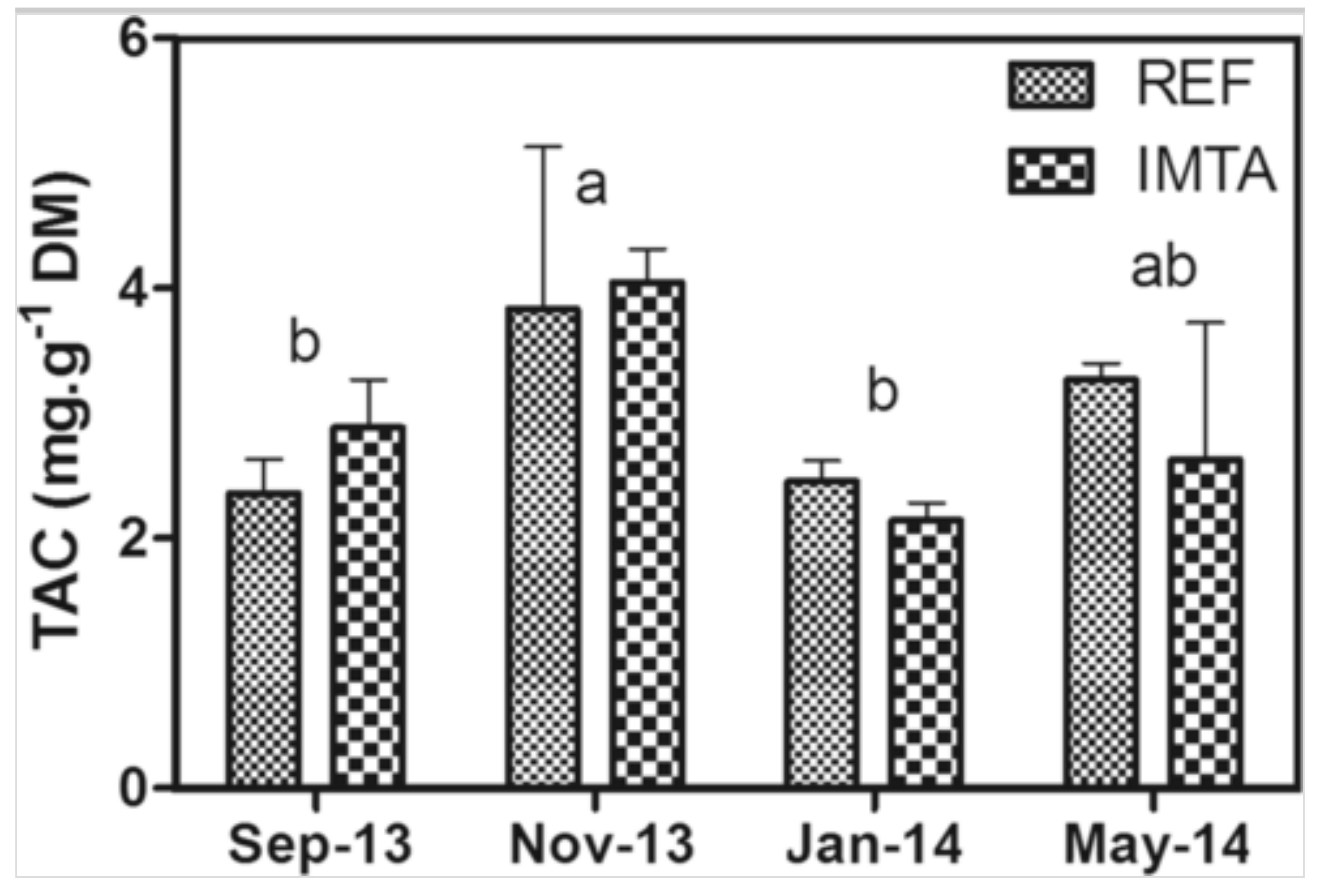

Regarding the HPLC-DAD results, it was not possible to identify any phenolic acids,-or flavonoids or phloroglucinol. Unidentified peaks were detected in all 
seaweed samples (Fig. 7), but their retention times and spectra did not match those of the 1820 tested standard Corrected from 18 to 20. Since the total number of standards tested was 20, as stated in other parts of the manuscript. compounds (usercreated library).

\section{Fig. 7}

HPLC profile of Saccharina latissima harvested in November at the REF site registered at 255 and $280 \mathrm{~nm}$. *Unidentified peaks whose concentrations were above limit of detection determined for gallic acid and rutin

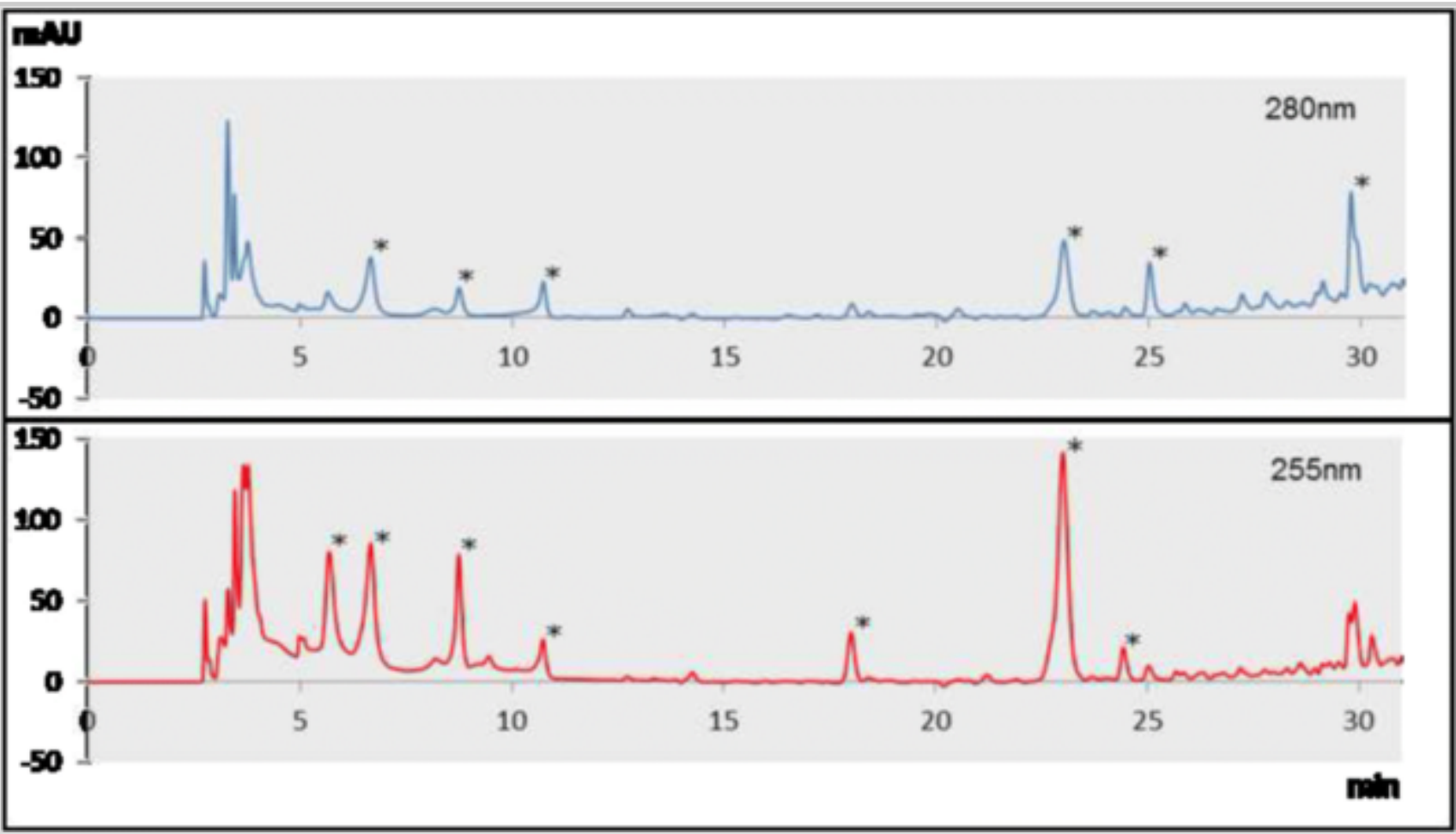

The pigment concentration varied during seasons; however, the profile remained unchanged, which included chlorophyll $a$ (ranging from 170169.52 to $655.12 \mu \mathrm{g} \mathrm{g}^{-1} \mathrm{DM}$ ) and fucoxanthin as dominant pigments, and with minor concentrations of other chlorophylls (c2) and other carotenoids (violaxanthin and $\beta$-carotene; Table 1). Fucoxanthin concentration was significantly higher in November, January, and May 2014 (261-665 $\left.\mu \mathrm{g} \mathrm{g}^{-1} \mathrm{DM}\right)$ compared to that in September $\left(222-370 \mu \mathrm{g} \mathrm{g}^{-1} \mathrm{DM} ; p<0.05\right.$; Fig. 8). No significant differences in the concentration of fucoxanthin were found between cultivation sites $(F=$ $0.014, p=0.92)$.

Table 1

Pigment composition ( $\mu \mathrm{g} \mathrm{g}^{-1} \mathrm{DM}$ ) of Saccharina latissima harvested in different seasons at IMTA and REF sites 


\begin{tabular}{|c|c|c|c|c|c|c|c|}
\hline \multirow[b]{2}{*}{ Pigments } & \multirow{2}{*}{$\begin{array}{l}\text { May } \\
\text { INITIAL }\end{array}$} & \multicolumn{2}{|c|}{ September } & \multicolumn{2}{|c|}{ November } & \multicolumn{2}{|c|}{ Januar. } \\
\hline & & REF & IMTA & REF & IMTA & REF & IM \\
\hline $\begin{array}{l}\text { Chlorophyll } \\
c 2\end{array}$ & n.d. & $\begin{array}{l}39.63 \\
\pm \\
12.12\end{array}$ & $\begin{array}{l}59.49 \\
\pm 7.11\end{array}$ & $\begin{array}{l}93.51 \\
\pm \\
78.56\end{array}$ & $\begin{array}{l}85.72 \\
\pm 8.44\end{array}$ & $\begin{array}{l}81.12 \\
\pm \\
18.30\end{array}$ & $\begin{array}{l}10 \\
\pm \\
40\end{array}$ \\
\hline Fucoxanthin & $120.3^{*}$ & $\begin{array}{l}221.6 \\
\pm \\
57.766\end{array}$ & $\begin{array}{l}369.9 \\
\pm \\
61.44\end{array}$ & $\begin{array}{l}541.5 \\
\pm \\
393.9\end{array}$ & $\begin{array}{l}628.9 \\
\pm \\
45.5 \theta\end{array}$ & $\begin{array}{l}511.4 \\
\pm \\
108.6\end{array}$ & $\begin{array}{l}66 \\
\pm \\
18\end{array}$ \\
\hline Violaxanthin & $3.79 \pm 3.34$ & $\begin{array}{l}16.29 \\
\pm 3.39\end{array}$ & $\begin{array}{l}22.71 \\
\pm \\
3.14\end{array}$ & $\begin{array}{l}35.88 \\
\pm \\
26.88\end{array}$ & $\begin{array}{l}33.68 \\
\pm 1.87\end{array}$ & $\begin{array}{l}26.65 \\
\pm \\
14.04\end{array}$ & $\begin{array}{l}32 \\
\pm \\
14\end{array}$ \\
\hline $\begin{array}{l}\text { Chlorophyll } \\
a\end{array}$ & $169.5 \pm 62.0 z$ & $\begin{array}{l}282.1 \\
\pm \\
43.44\end{array}$ & $\begin{array}{l}406.2 \\
\pm \\
38.6 z\end{array}$ & $\begin{array}{l}655.1 \\
\pm \\
503.6\end{array}$ & $\begin{array}{l}512.9 \\
\pm \\
79.0 \theta\end{array}$ & $\begin{array}{l}465.7 \\
\pm \\
323.0\end{array}$ & $\begin{array}{l}63 \\
\pm \\
23\end{array}$ \\
\hline$\beta$-carotene & $3.88 \pm 0.71$ & $\begin{array}{l}8.76 \pm \\
4.73\end{array}$ & $\begin{array}{l}5.29 \\
\pm \\
2.14\end{array}$ & $\begin{array}{l}19.67 \\
\pm \\
3.10\end{array}$ & $\begin{array}{l}15.90 \\
\pm 3.15\end{array}$ & $\begin{array}{l}19.52 \\
\pm \\
7.24\end{array}$ & $\begin{array}{l}23 \\
\pm 7\end{array}$ \\
\hline $\begin{array}{l}\text { Total } \\
\text { carotenoids }\end{array}$ & $65.92 \pm 86.44$ & $\begin{array}{l}246.7 \\
\pm \\
65.7 \theta\end{array}$ & $\begin{array}{l}397.9 \\
\pm \\
66.44\end{array}$ & $\begin{array}{l}590.5 \\
\pm \\
432.3\end{array}$ & $\begin{array}{l}678.5 \\
\pm \\
42.108\end{array}$ & $\begin{array}{l}557.6 \\
\pm \\
128.7\end{array}$ & $\begin{array}{l}72 \\
\pm \\
20\end{array}$ \\
\hline $\begin{array}{l}\text { Total } \\
\text { chlorophylls }\end{array}$ & $\begin{array}{l}177.9169 .5 \pm \text { An error } \\
\text { was found here and the } \\
\text { numbers were corrected } \\
\text { accordinalv. This does not } \\
\text { have anv imbact elsewhere } \\
\text { in the manuscritpt. } \\
50.1862 .0\end{array}$ & $\begin{array}{l}321.7 \\
\pm \\
55.51\end{array}$ & $\begin{array}{l}465.7 \\
\pm \\
41.3 z\end{array}$ & $\begin{array}{l}748.6 \\
\pm \\
582.2\end{array}$ & $\begin{array}{l}598.6 \\
\pm \\
87.4 \theta\end{array}$ & $\begin{array}{l}546.8 \\
\pm \\
338.0\end{array}$ & $\begin{array}{l}74 \\
\pm \\
27\end{array}$ \\
\hline
\end{tabular}

Data expressed as mean \pm standard deviation $(n=3) . *$ Detected in only one experimenta n.d., not detected

\section{Fig. 8}

Fucoxanthin content of Saccharina latissima harvested in different seasons, and cultivated both at the IMTA and REF sites. Different letters represent significant difference $(p<0.05)$ between months. Data are mean $\pm \mathrm{SD} ; n=3$ 


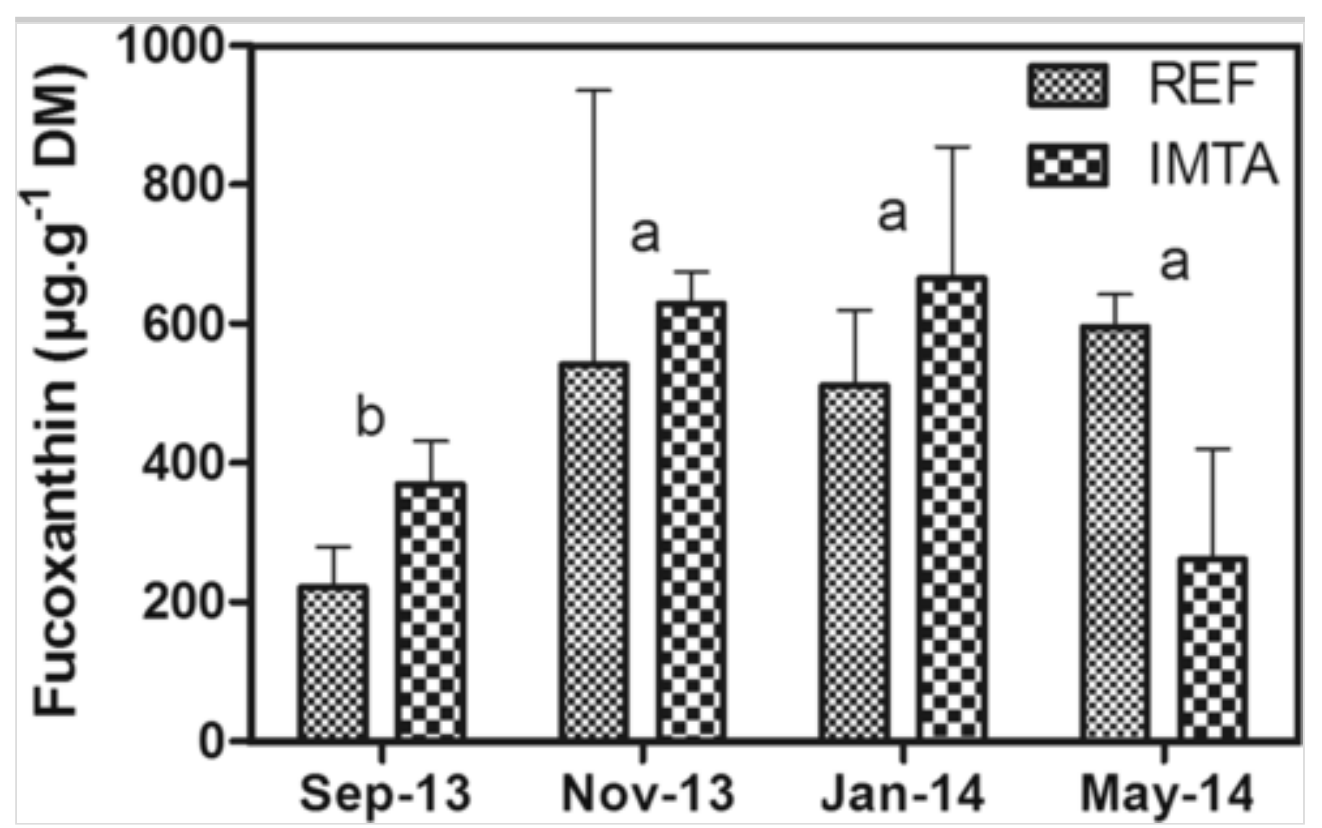

DPPH radical scavenging activity revealed a concentration dependency and increased with increasing concentrations of algal extract (data not shown). $\mathrm{IC}_{50}$ ranged from a minimum of $0.42 \mathrm{mg} \mathrm{mL}^{-1}$ in September to a maximum of $2.81 \mathrm{mg} \mathrm{mL}^{-1}$ in May 2014 (Fig. 9). Nevertheless, difference in the DPPH radical scavenging activity between harvest times was not statistically significant $(F=2.13, p=0.21)$.

Fig. 9

DPPH radical scavenging activity $\left(\mathrm{IC}_{50} ; \mathrm{mg} \mathrm{mL} \mathrm{mL}^{-1}\right)$ of methanol extracts of Saccharina latissima harvested in different seasons at the REF site. Data are mean $\pm \mathrm{SD} ; n=3$

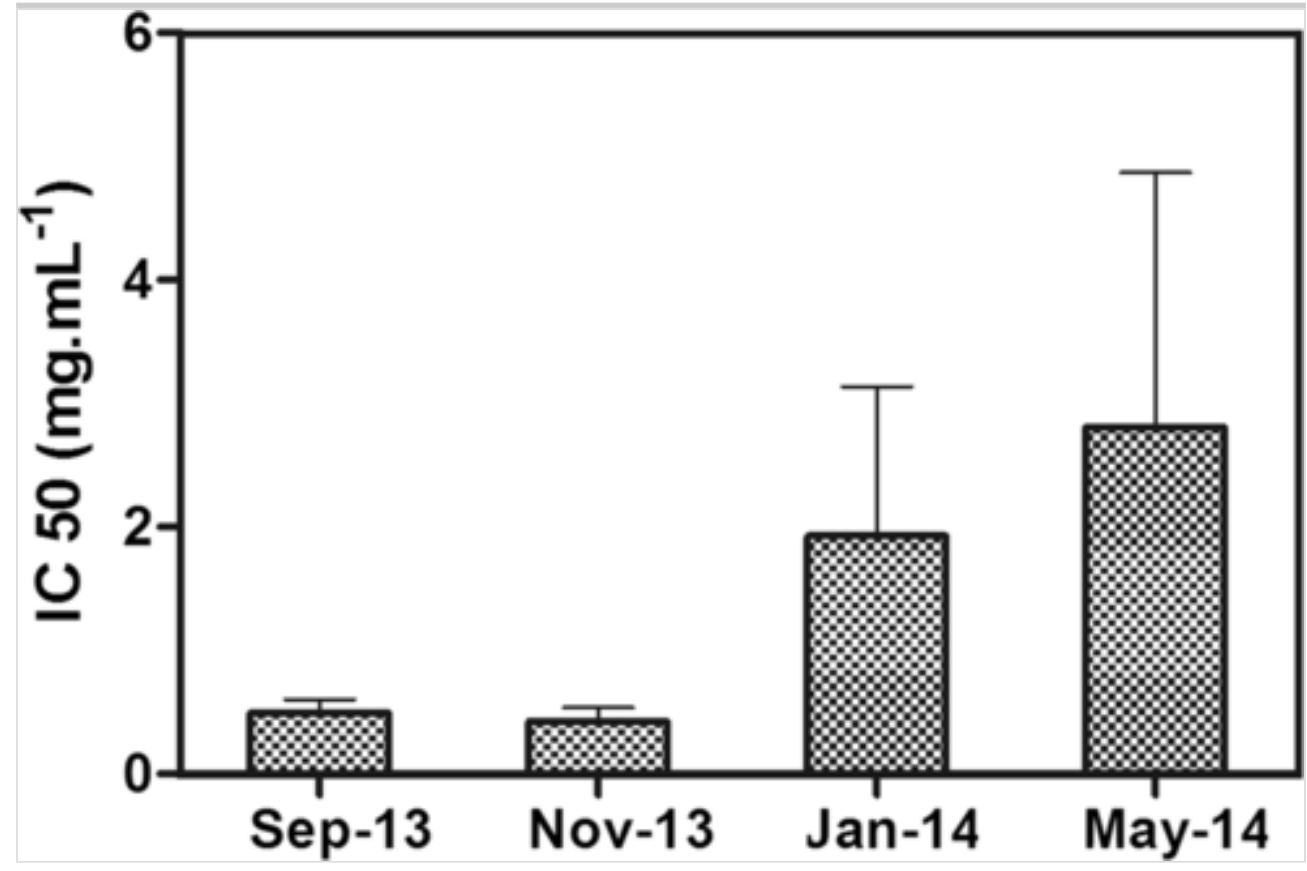




\section{Correlation between antioxidant content and activity}

Effect of variations of TPC, TFC, and fucoxanthin contents as independent variables on the variation of $\mathrm{IC}_{50}$ has been tested by a multiple least square regression model. Analysies of variances results showed weak correlation between the parameters ( $F=2.82$ and $p=0.12$ at the $5.0 \%$ significance level). Partial least square plot showed that fucoxanthin had the main effect on the variations of $\mathrm{IC}_{50}$, with fucoxanthin increase leading to a reduction in antiradical activity (Fig. 10(a)). On the other hand, both TPC and TFC were negatively correlated to $\mathrm{IC}_{50}$, suggesting that these variables had a positive effect on the radical scavenging activity, especially TPC. Moreover, the combination of TPC and fucoxanthin contents showed strong correlation with TAC as dependent variable $(F=11.67, p<0.005)$. Partial least square model showed that both independent variables positively contributed to the variations in TAC, with TPC as the main contributing factor (Fig. 10(b)).

Fig. 10

Partial least square (PLS) coefficient plots showing the standardized coefficient for effect of the independent variables TPC (mg GAE $\mathrm{g}^{-1} \mathrm{DM}$ ), TFC (mg RE g ${ }^{-1}$ $\mathrm{DM}$ ), and fucoxanthin ( $\mu \mathrm{g} \mathrm{g}^{-1} \mathrm{DM}$ ) on (a) $\mathrm{IC}_{50}$ values for the $\mathrm{DPPH}$ scavenging activity, and (b) TAC 


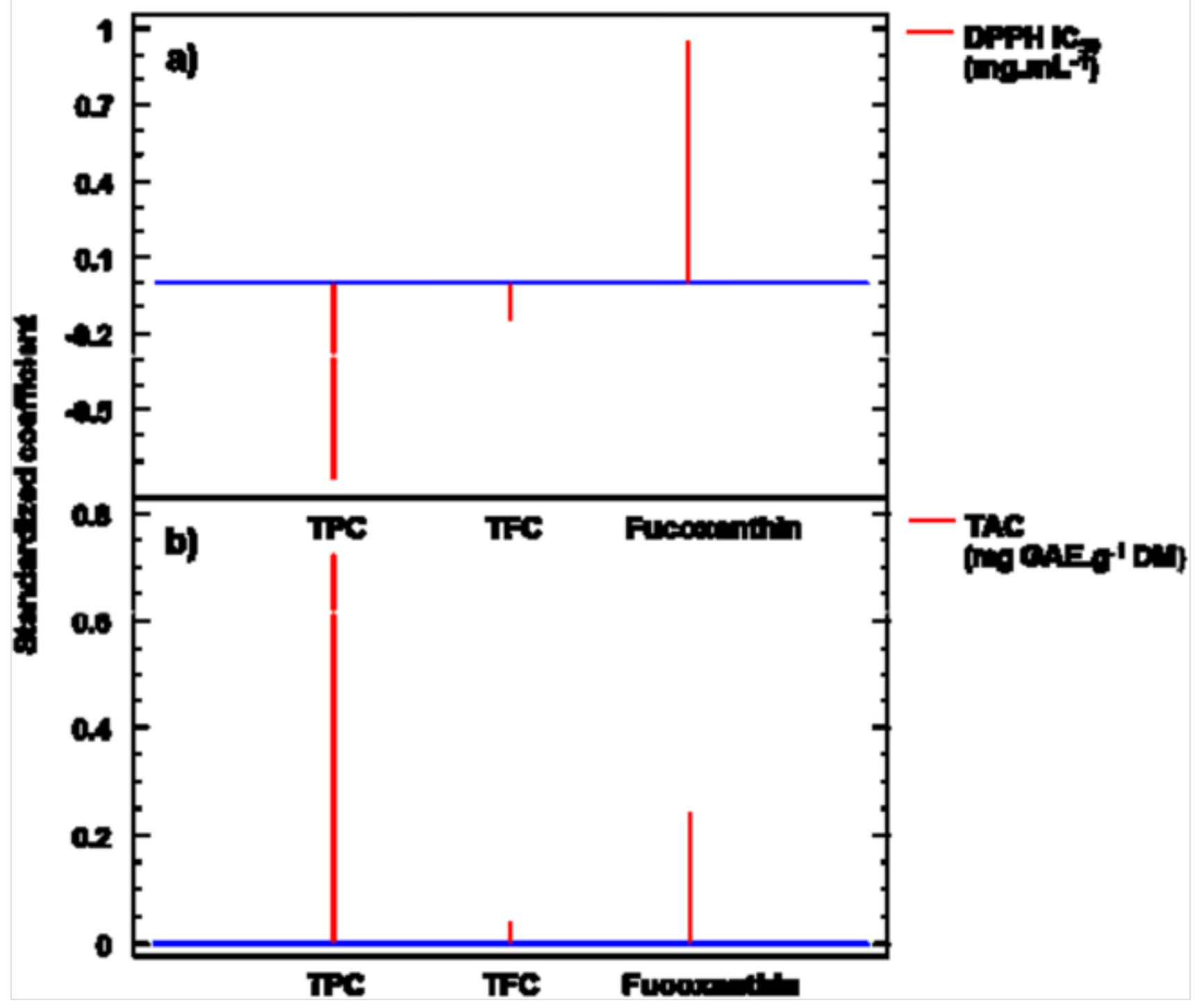

\section{Discussion}

The results obtained for the TPC, TFC, and TAC assays were affected by the solvent applied for the extraction process. Methanol extraction resulted in higher values than ethyl acetate except for few months in the TFC assay. Our observations are most likely due to the polarity of the solvents applied (methanol is a more polar solvent than ethyl acetate) and polarity of the antioxidative compounds present in the seaweed. Several studies have been performed on the antioxidative properties of seaweed extracts, where different extraction solvents resulted in different results for the antioxidant properties and effects (Cho et al. 2007; Farvin and Jacobsen 2013; Hermund et al. 2015; Honold et al. 2016). Koivikko et al. (2005) reported a general increase in the extraction efficiency of phenolic compounds (phlorotannins) from the brown seaweed Fucus vesiculosus with increasing solvent polarity. Furthermore, our findings are in accordance with the results reported on pomegranate fruit, where methanol extraction resulted in much higher total phenolic and total flavonoid contents than ethyl 
acetate. The differences observed were in that study also ascribed to the differences in the polarity of the applied solvents (Ali et al. 2014).

Generally, cultivation site did not result in significant difference on the tested variables, while significant seasonal differences were identified for the TPC, TFC, and TAC assays. Similarity in these variables between cultivation sites may be explained by the similar environmental conditions found in the two cultivation areas including water temperature, salinity, irradiance, and inorganic nitrogen and phosphorus. Moreover, the inorganic nutrients released from the fish farm at the IMTA site were considered negligible compared to the naturally occurring background concentrations of nitrogen (Marinho et al. 2015c).

The TPC found in this study was several times higher than that previously reported for water $\left(209 \mu \mathrm{g} \mathrm{GAE} \mathrm{g}^{-1} \mathrm{DM}\right)$ and ethanol extracts $\left(354 \mu \mathrm{g} \mathrm{GAE} \mathrm{g}^{-1}\right.$ DM) of S. latissima (Farvin and Jacobsen 2013). Likely, this difference may be related to the different polarity of the solvents applied. On the other hand, the concentrations reported here for S. latissima $\left(0.84-2.41 \mathrm{mg} \mathrm{GAE}^{-1} \mathrm{DM}\right)$ are similar to those reported for $L$. digitata harvested monthly in a sheltered rocky shore in Brittany (France), ranging seasonally from 0.09 to $0.19 \%$ DM (using phloroglucinol as standard; Connan et al. 2004). Likewise, the seasonal variation on the TPC followed the pattern reported for L. digitata in the same study with the highest values found in winter and lowest values found in summer/autumn. On the other hand, Yates and Peckol (1993) observed an opposite trend in natural populations of $F$. vesiculosus, where the lowest concentrations of polyphenols were found from November to February. Moreover, the authors found that the concentration of polyphenols was negatively correlated with the ambient $\mathrm{N}$ concentration and tissue-N content (Yates and Peckol 1993). These results are contrary to those reported in our study, since both ambient nutrient concentrations and tissue-N content of S. latissima are highest during winter in the inner Danish waters (Marinho et al. 2015c). The highest concentrations found for $S$. latissima are at least 10 times lower compared with the values reported by Connan et al. (2004) for seven species from the order Fucales. Our results further support that species belonging to the order Laminariales present substantially lower content of total phenolics compared with those belonging to the order Fucales (e.g., Fucus sp.).

To our knowledge, this is the first report on TFC of S. latissima. TFC varied seasonally reaching a maximum in summer and a minimum in winter.

Flavonoids are UV-absorbing compounds functioning as UV screen in terrestrial plants, among many other important functions. For instance, quercetin can be induced by UV-B and is primarily found in the epidermal cells. This role is assumed to be played by simpler UV-absorbing compounds such as 
mycosporine-like amino acids in the aquatic environment (Rozema et al. 2002). Nevertheless, structural identification of flavonoids in red and brown seaweeds, and microalgae, has recently been reported, contradicting the general assumption that these compounds could be exclusively present in terrestrial plants (Klejdus et al. 2010; Rodríguez-Bernaldo de Quirós et al. 2010; Goiris et al. 2014). TFC found in the present study (1.40-4.83 $\mathrm{mg} \mathrm{RE} \mathrm{g}^{-1} \mathrm{DM}$ over all seasons) is much higher than that found in a number of brown and green seaweed species originated from the Black Sea (6.5-229 $\left.\mu \mathrm{g} \mathrm{RE} \mathrm{g}^{-1} \mathrm{DM}\right)$, and higher but comparable to the values found in brown and green species from Rameshwaram Ecoast of India (1.35-2.02 mg GAE/g; Meenakshi et al. 2009; Sava and Sîrbu 2010). On the other hand, our values are considerably lower compared with those reported in another study testing seaweed species belonging to the three majorgroups: green, red, and brown seaweeds, harvested from the Visakhapatnam coast of India (6.03-33.439 mg quercetin equivalents ... Should this punctuation be removed? $\mathrm{g}^{-1} \mathrm{DM}$; Sarojini et al. 2012). Nevertheless, because of the differences in the extraction methods, solvents applied, and species tested comparisons among studies, should be carefully considered.

$\mathrm{AQ} 4$

The pigment qualitative composition did not change seasonally, whereas chlorophyll $a$ and fucoxanthin were the dominant pigments. Fucoxanthin has been previously identified as a major pigment found in brown seaweed species (Holdt and Kraan 2011), which may account to $79 \%$ of total carotenoids (Haugan and Liaaen-Jensen 1994). On the other hand, the quantity of specific pigments changed seasonally, and with fucoxanthin concentrations that could be of commercial interest, varying seasonally from 222 to $665 \mu \mathrm{g} \mathrm{g}^{-1} \mathrm{DM}$ of $S$. latissima. Although, the concentrations of fucoxanthin in S. latissima are in the lower end of the range of values reported for fucoxanthin-rich microalgae such as diatoms (700-21,670 $\mu \mathrm{g} \mathrm{g}^{-1} \mathrm{DM}$; Petrushkina et al. 2017), efficient commercial-scale extraction of fucoxanthin from processing discards of seaweed (Saccharina japonica) has already been established, reaching a recovery ratio of $82 \%$. Moreover, the fucoxanthin obtained was stable and reduced by only $2 \%$ after a 6-month storage at $4{ }^{\circ} \mathrm{C}$ (Kanazawa et al. 2008). Concentration of fucoxanthin found in a number of Norwegian brown seaweed species ranged from 172 to $720 \mu \mathrm{g} \mathrm{g}^{-1} \mathrm{DM}$ (Jensen 1966), which matches the range of values reported here for $S$. latissima harvested at different seasons. Our results reveal a seasonal pattern in the concentration of fucoxanthin which ranged from a summer minimum to an autumn/winter maximum. A similar seasonal pattern on the concentration of fucoxanthin was also observed in the brown seaweed Ascophyllum nodosum (Stengel and Dring 1998). Furthermore, the increased fucoxanthin content observed during autumn/winter in this study is supported by studies showing that this increase can be a response to, i.e., shade and/or depth 
adaptation in order to increase light-harvesting efficiency (Ramus et al. 1977; Fortes and Lüning 1980). This can be correlated with less irradiance and short day length observed during winter in Denmark.

Seasonal changes in DPPH radical scavenging activity were not of statistical significance, which likely resulted from the high biological variability observed in the samples collected in January and May (very high standard deviation). Nevertheless, the lowest $\mathrm{IC}_{50}$ values, corresponding to the highest radical scavenging activity, were found in September and November, matching the period in which the maximum concentrations of TFC and TPC were found, respectively. This data suggested a possible correlation between DPPH scavenging activity and TFC and TPC. This assumption was further supported by the partial least square coefficient plot revealing that both TPC and TFC were negatively correlated with $\mathrm{IC}_{50}$, suggesting that these variables had a positive effect on the radical scavenging activity. These results are in accordance with previous studies, which directly correlated DPPH scavenging activity with the TPC found in the extracts both in seaweeds (e.g., Cho et al. 2007; Wang et al. 2009, 2012; Hermund et al. 2015) and in plants (e.g., Ghasemzadeh et al. 2010; Ali et al. 2014). On the other hand, the analysis revealed a strong positive correlation between fucoxanthin and $\mathrm{IC}_{50}$, which could suggest a negative impact of fucoxanthin in the radical scavenging activity. However, fucoxanthin has been reported to have strong radical scavenging activity in a number of studies (e.g., Sachindra et al. 2007; Peng et al. 2011; Farvin et al. 2018). Thus, it is likely that our results are impacted by the presence of other compounds in the seaweed extracts such as specific phenolic compounds, low-molecular-weight polysaccharides, proteins, or peptides which may contribute to free radical scavenging activity (Farvin and Jacobsen 2013). Additionally, the regression analysis revealed a strong positive correlation between TPC and TAC assays. This result supports previous studies suggesting that polyphenols are a main contributing factor for TAC, which act by donating electrons and reacting with free radicals to convert them into more stable product and terminate free radical chain reaction (Jayaprakasha et al. 2003; Kasangana et al. 2015).

Using both retention times and spectral matching (DAD), it was not possible to find a positive match between the tested 20 phenolic standards and the peaks detected in the seaweed samples. It can be hypothesized that phenolic compounds may be oxidized during prolonged storage, and/or their concentrations may be below the limit of detection of the HPLC-DAD method, or the selected phenolic compounds are not present in the seaweed. On the other hand, considering that more than 8000 phenolic compounds have been identified so far (Guo et al. 2009), it is possible that seaweed may contain other phenolic compounds than the ones evaluated in this study. In this context, there is a great 
need for further research to investigate the composition of phenolic compounds in seaweed, particularly using analytical methods suitable for structural identification such as NMR and/or HPLC-MS.

\section{Conclusion}

Methanol seems to be more suitable than ethyl acetate for extracting antioxidants from seaweed.

This study did not find any differences in biomass between the IMTA and the reference site, but demonstrates seasonal changes in the content of total phenolics, total flavonoids, and pigments, and the subsequent total antioxidant capacity of cultivated $S$. latissima, which needs to be taken into consideration when evaluating this species as a source of antioxidants. Overall, biomass harvested in November presented a combination of higher TPC, TAC, fucoxanthin, and radical scavenging activity, and thus this seems to be the prime harvest time when targeting antioxidant content and activity. TPC and TFC had a positive effect on the radical scavenging activity, especially TPC, which likewise contributed most for TAC.

Saccharina latissima had fucoxanthin as a major pigment, which may be of commercial interest due to its numerous reported bioactivities and established efficient commercial-scale extraction process. Saccharina latissima is not the species with the highest antioxidant capacity, but accounting that species from the order Fucales such as Fucus sp. are not yet in cultivation, the harvestable volumes, and thereby overall yields of antioxidants from S. latissima, may be higher and of commercial interest.

\section{Acknowledgements}

Thanks are due to our project partners: Danish Aquaculture Organization, Orbicon, DHI, TrippleNine, and Hjarnø Havbrug A/S. Special thanks are due to Hjarnø Havbrug A/S for providing practical help and logistics at sea.

Funding information

AQ5

This study was supported by The Danish AgriFish Agency (GUDP)—Grant No. 3405-11-0375.

\section{References}

Ali SI, El-Baz FK, El-Emary GAE, Khan EA, Mohamed AA (2014) HPLCanalysis of polyphenolic compounds and free radical scavenging activity of 
pomegranate fruit (Punica granatum L.). Int J Pharm Clin Res 6:348-355

Anderson M, Gorley R, Clarke K (2008) PERMANOVA+ for PRIMER: guide to software and statistical methods. PRIMER-E, Plymouth

Arasaki S, Arasaki T (1983) Low calorie, high nutrition vegetables from the sea to help you look and feel better. Japan Publications Inc., Tokyo

Azevedo IC, Marinho GS, Silva DM, Sousa-Pinto I (2016) Pilot scale landbased cultivation of Saccharina latissima Linnaeus at southern European climate conditions: growth and nutrient uptake at high temperatures. Aquaculture 459:166-172

Bixler HJ, Porse H (2011) A decade of change in the seaweed hydrocolloids industry. J Appl Phycol 23:321-335

Cho S, Kang S, Cho J, Kim AR, Park SM, Hong YK, Ahn DH (2007) The antioxidant properties of brown seaweed (Sargassum siliquastrum) extracts. J Med Food 10:479-485

Connan S, Goulard F, Stiger V, Deslandes E, Ar Gall E (2004) Interspecific and temporal variation in phlorotannin levels in an assemblage of brown algae. Bot Mar 47:410-416

FAO (2018) Fishery statistical collections. Global Aquaculture Production. http://www.fao.org/fishery/statistics/global-aquaculture-production/en . Accessed 16 Feb 2018

Fariman GA, Shastan SJ, Zahedi MM (2016) Seasonal variation of total lipid, fatty acids, fucoxanthin content, and antioxidant properties of two tropical brown algae (Nizamuddinia zanardinii and Cystoseira indica) from Iran. J Appl Phycol 28:1323-1331

Farvin KHS, Jacobsen C (2013) Phenolic compounds and antioxidant activities of selected species of seaweeds from Danish coast. Food Chem 138:1670-1681

Farvin KHS, Jacobsen C (2015) Antioxidant activity of seaweed extracts: in vitro assays, evaluation in 5\% fish oil-in-water emulsions and characterization. J Am Oil Chem Soc 92:571-587 
Farvin KHS, Andersen LL, Nielsen HH, Jacobsen C, Jakobsen G, Johansson I, Jessen F (2014) Antioxidant activity of cod (Gadus morhua) protein hydrolysates: In vitro assays and evaluation in 5\% fish oil-in-water emulsion. Food Chem 149:326-334

Farvin KHS, Surendraraj A, Jacobsen C (2018) Isolation of fucoxanthin from brown algae and its antioxidant activity: in vitro and 5\% fish oil-in-water emulsion. J Am Oil Chem Soc 95:835-843

Fortes MD, Lüning K (1980) Growth rates of North Sea macroalgae in relation to temperature, irradiance and photoperiod. Helgol Meeresunters $34: 15-29$

Ghasemzadeh A, Jaafar HZE, Rahmat A (2010) Antioxidant activities, total phenolics and flavonoids content in two varieties of Malaysia young ginger (Zingiber officinale Roscoe). Molecules 15:4324-4333

Goiris K, Muylaert K, Voorspoels S, Noten B, De Paepe D, E Baart GJ, De Cooman L (2014) Detection of flavonoids in microalgae from different evolutionary lineages. J Phycol 50:483-492

Guo W, Kong E, Meydani M (2009) Dietary

Handå A, Forbord S, Wang X, Broch OJ, Dahle SW, Størseth TR, Reitan KI, Olsen Y, Skjermo J (2013) Seasonal- and depth-dependent growth of cultivated kelp (Saccharina latissima) in close proximity to salmon (Salmo salar) aquaculture in Norway. Aquaculture 414-415:191-201

Haugan JA, Liaaen-Jensen S (1994) Algal carotenoids 54. Carotenoids of brown algae (Phaeophyceae). Biochem Syst Ecol 22:31-41

Hermund DB, Yeşiltaş B, Honold P, Jónsdóttir R, Kristinsson HG, Jacobsen C (2015) Characterisation and antioxidant evaluation of Icelandic F. vesiculosus extracts in vitro and in fish-oil-enriched milk and mayonnaise. J Funct Foods 19:828-841

Holdt SL, Kraan S (2011) Bioactive compounds in seaweed: functional food applications and legislation. J Appl Phycol 23:543-597

Honold PJ, Jacobsen C, Jónsdóttir R, Kristinsson HG, Hermund DB (2016) Potential seaweed-based food ingredients to inhibit lipid oxidation in fish-oilenriched mayonnaise. Eur Food Res Technol 242:571-584 
Jacobsen C, Sørensen A-DM, Holdt SL, et al (2018) Novel antioxidants from seaweed. Manuscript submitted to Annu Rev Food Sci Technol

Jayaprakasha GK, Selvi T, Sakariah KK (2003) Antibacterial and antioxidant activities of grape (Vitis vinifera) seed extracts. Food Res Int 36:117-122

Jensen A (1966) Carotenoids of Norwegian brown seaweeds and of seaweed meals. Norwegian Institute of Seaweed Research, Report No. 31. Tapir, Trondheim

Kamiya M, Nishio T, Yokoyama A, Yatsuya K, Nishigaki T, Yoshikawa S, Ohki K (2010) Seasonal variation of phlorotannin in sargassacean species from the coast of the sea of Japan. Phycol Res 58:53-61

Kanazawa K, Ozaki Y, Hashimoto T, Das SK, Matsushita S, Hirano M, Okada T, Komoto A, Mori N, Nakatsuka M (2008) Commercial-scale preparation of biofunctional fucoxanthin from waste parts of brown sea algae Laminaria japonica. Food Sci Technol Res 14:573-582

Karadağ A, Hermund DB, Jensen LHS, Andersen U, Jónsdóttir R, Kristinsson HG, Alasalvar C, Jacobsen C (2017) Oxidative stability and microstructure of $5 \%$ fish-oil-enriched granola bars added natural antioxidants derived from brown alga Fucus vesiculosus. Eur J Lipid Sci Technol 119:1500578

Kasangana P, Haddad P, Stevanovic T (2015) Study of polyphenol content and antioxidant capacity of Myrianthus Arboreus (Cecropiaceae) root bark extracts. Antioxidants 4:410-426

Klejdus B, Lojková L, Plaza M, Snóblová M, Stěrbová D (2010) Hyphenated technique for the extraction and determination of isoflavones in algae: ultrasound-assisted supercritical fluid extraction followed by fast chromatography with tandem mass spectrometry. J Chromatogr A 1217:7956-7965

Koivikko R, Loponen J, Honkanen T, Jormalainen V (2005) Contents of soluble, cell-wall-bound and exuded phlorotannins in the brown alga Fucus vesiculosus, with implications on their ecological functions. J Chem Ecol 31:195-212

Mannino AM, Vaglica V, Oddo E (2014) Seasonal variation in total phenolic content of Dictyopteris polypodioides (Dictyotaceae) and Cystoseira amentacea (Sargassaceae) from the Sicilian coast. Flora Mediterr 24:39-50 
Marinho G, Holdt S, Jacobsen C, Angelidaki I (2015a) Lipids and composition of fatty acids of Saccharina latissima cultivated year-round in integrated multi-trophic aquaculture. Mar Drugs 13:4357-4374

Marinho GS, Holdt SL, Angelidaki I (2015b) Seasonal variations in the amino acid profile and protein nutritional value of Saccharina latissima cultivated in a commercial IMTA system. J Appl Phycol 27:1991-2000

Marinho GS, Holdt SL, Birkeland MJ, Angelidaki I (2015c) Commercial cultivation and bioremediation potential of sugar kelp, Saccharina latissima, in Danish waters. J Appl Phycol 27:1963-1973

Meenakshi S, Gnanambigai DM, Tamil Mozhi S, Arumugam M, Balasubramanian T (2009) Total flavanoid and in vitro antioxidant activity of two seaweeds of Rameshwaram coast. Glob J Pharmacol 3:59-62

Mouritsen OG (2013) Seaweeds: edible, available \& sustainable. University of Chicago Press, Chicago

Pal A, Kamthania MC, Kumar A (2014) Bioactive compounds and properties of seaweeds-a review. OALib 01:1-17

Peng J, Yuan J-P, Wu C-F, Wang J-H (2011) Fucoxanthin, a marine carotenoid present in brown seaweeds and diatoms: metabolism and bioactivities relevant to human health. Mar Drugs 9:1806-1828

Peteiro C, Freire Ó (2013) Biomass yield and morphological features of the seaweed Saccharina latissima cultivated at two different sites in a coastal bay in the Atlantic coast of Spain. J Appl Phycol 25:205-213

Petrushkina M, Gusev E, Sorokin B, Zotko N, Mamaeva A, Filimonova A, Kulikovskiy M, Maltsev Y, Yampolsky I, Guglya E, Vinokurov V, Namsaraev Z, Kuzmin D (2017) Fucoxanthin production by heterokont microalgae. Algal Res 24:387-393

Poyato C, Thomsen BR, Hermund DB, Ansorena D, Astiasarán I, Jónsdóttir R, Kristinsson HG, Jacobsen C (2017) Antioxidant effect of water and acetone extracts of Fucus vesiculosus on oxidative stability of skin care emulsions. Eur J Lipid Sci Technol 119:1600072 
Prieto P, Pineda M, Aguilar M (1999) Spectrophotometric quantitation of antioxidant capacity through the formation of a phosphomolybdenum complex: specific application to the determination of vitamin E. Anal Biochem 269:337-341

Ramus J, Lemons F, Zimmerman C (1977) Adaptation of light-harvesting pigments to downwelling light and the consequent photosynthetic performance of the eulittoral rockweeds Ascophyllum nodosum and Fucus vesiculosus. Mar Biol 42:293-303

Rodríguez-Bernaldo de Quirós A, Lage-Yusty MA, López-Hernández J (2010) Determination of phenolic compounds in macroalgae for human consumption. Food Chem 121:634-638

Rozema J, Björn LO, Bornman JF, Gaberscik A, Häder DP, Trost T, Germ M, Klisch M, Gröniger A, Sinha RP, Lebert M, He YY, Buffoni-Hall R, de Bakker NV, van de Staaij J, Meijkamp BB (2002) The role of UV-B radiation in aquatic and terrestrial ecosystems - an experimental and functional analysis of the evolution of UV-absorbing compounds. J Photochem Photobiol B 66:2-12

Sachindra NM, Sato E, Maeda H, Hosokawa M, Niwano Y, Kohno M, Miyashita K (2007) Radical scavenging and singlet oxygen quenching activity of marine carotenoid fucoxanthin and its metabolites. J Agric Food Chem 55:8516-8522

Safafar H, van Wagenen J, Møller P, Jacobsen C (2015) Carotenoids, phenolic compounds and tocopherols contribute to the antioxidative properties of some microalgae species grown on industrial wastewater. Mar Drugs 13:7339-7356

Sarojini Y, Lakshminarayana K, Rao PS (2012) Variations in distribution of flavonoids in some seaweed of Visakhapatnam coast of India. Der Pharma Chem 4:1481-1484

Sava C, Sîrbu R (2010) Analytical study of the determination of flavonoids in Black Sea algae. Ovidius Univ Ann Chem 21:29-34

Schmid M, Guihéneuf F, Stengel DB (2017) Ecological and commercial implications of temporal and spatial variability in the composition of pigments and fatty acids in five Irish macroalgae. Mar Biol 164:1-18 
Shahidi F, Zhong Y, Chandrasekara A (2012) Antioxidants and human health. In: Yu LL, Tsao R, Shahidi F (eds) Cereals and Pulses: Nutraceutical Properties and Health Benefits, 1st edn. John Wiley \& Sons, Inc., Hoboken, pp 273-308

Sherwin ER (1990) Antioxidants. In: Branen L, Davidson PM, Salminen S (eds) Food additives. Marcel Dekker, New York, pp 139-193

Singh IP, Sidana J (2013) Phlorotannins. In: Functional ingredients from algae for foods and nutraceuticals. Elsevier, pp 181-204

Singleton VL, Rossi JA (1965) Colorimetry of total phenolics with phosphomolybdic-phosphotungstic acid reagents. Am J Enol Vitic 16:144158

Steinberg PD (1995) Seasonal variation in the relationship between growth rate and phlorotannin production in the kelp Ecklonia radiata. Oecologia 102:169-173

Stengel DB, Dring MJ (1998) Seasonal variation in the pigment content and photosynthesis of different thallus regions of Ascophyllum nodosum (Fucales, Phaeophyta) in relation to position in the canopy. Phycologia 37:259-268

Stiger V, Deslandes E, Payri CE (2004) Phenolic contents of two brown algae, Turbinaria ornata and Sargassum mangarevense on Tahiti (French Polynesia): interspecific, ontogenic and spatio-temporal variations. Bot Mar 47:402-409

Tabarsa M, Rezaei M, Ramezanpour Z, Waaland R, Rabiei R (2012) Fatty acids, amino acids, mineral contents, and proximate composition of some brown seaweeds. J Phycol 48:285-292

Wang T, Jónsdóttir R, Ólafsdóttir G (2009) Total phenolic compounds, radical scavenging and metal chelation of extracts from Icelandic seaweeds. Food Chem 116:240-248

Wang T, Jónsdóttir R, Liu H, Gu L, Kristinsson HG, Raghavan S, Olafsdóttir $\mathrm{G}$ (2012) Antioxidant capacities of phlorotannins extracted from the brown algae Fucus vesiculosus. J Agric Food Chem 60:5874-5883

Wattenberg LW (1986) Protective effects of 2(3)-tert-butyl-4-hydroxyanisole on chemical carcinogenesis. Food Chem Toxicol 24:1099-1102 
Yates JL, Peckol P (1993) Effects of nutrient availability and herbivory on polyphenolics in the seaweed Fucus vesiculosus. Ecology 74:1757-1766 